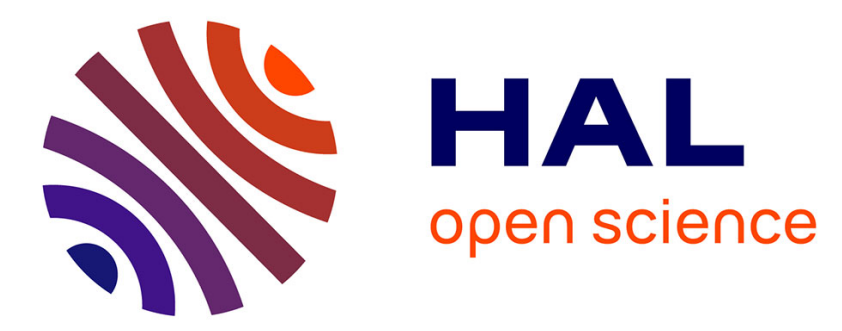

\title{
Decrease in cross-border tobacco purchases despite intensification of antitobacco policies in France
}

Ramchandar Gomajee, Hugo Torregrossa, Camille Bolze, Maria Melchior, Fabienne El-Khoury Lesueur

\section{- To cite this version:}

Ramchandar Gomajee, Hugo Torregrossa, Camille Bolze, Maria Melchior, Fabienne El-Khoury Lesueur. Decrease in cross-border tobacco purchases despite intensification of antitobacco policies in France. Tobacco Control, In press, 10.1136/tobaccocontrol-2019-055540 . hal-02941684

\section{HAL Id: hal-02941684 https://hal.sorbonne-universite.fr/hal-02941684}

Submitted on 17 Sep 2020

HAL is a multi-disciplinary open access archive for the deposit and dissemination of scientific research documents, whether they are published or not. The documents may come from teaching and research institutions in France or abroad, or from public or private research centers.
L'archive ouverte pluridisciplinaire HAL, est destinée au dépôt et à la diffusion de documents scientifiques de niveau recherche, publiés ou non, émanant des établissements d'enseignement et de recherche français ou étrangers, des laboratoires publics ou privés. 
Decrease in cross-border tobacco purchases despite intensification of anti-tobacco policies in France.

Ramchandar Gomajee $^{1}$; Hugo Torregrossa ${ }^{1}$; Camille Bolze ${ }^{1}$; Maria Melchior ${ }^{1}$; Fabienne ElKhoury Lesueur ${ }^{1}$

1. INSERM, Sorbonne Université, Institut Pierre Louis d'Epidémiologie et de Santé Publique (IPLESP), Department of Social Epidemiology, 75012 Paris, France

\section{Corresponding author :}

Ramchandar Gomajee

INSERM, Sorbonne Université, Institut Pierre Louis d'Epidémiologie et de Santé Publique (IPLESP), Department of Social Epidemiology,

Hôpital St Antoine,

27 rue Chaligny,

75012 Paris, France

ramchandar.gomajee@inserm.fr

Tel: 0033185560243

Keywords: Smoking topography, Packaging and Labelling, Public policy, Price, Surveillance and monitoring

Word count: 3,049

Reference count: 41 


\begin{abstract}
Background

Recently, France has intensified tobacco control policies which included gradual increase in tobacco products price and the introduction of plain packaging. However, there has been suggestion that cross-border tobacco purchases from neighbouring countries, with lower tobacco prices, will increase. We examine trends in cross-border tobacco purchases among smokers concurrent with the implementation of tobacco control measures between 2016 and 2017.
\end{abstract}

\title{
Methods
}

DePICT is a two-wave cross-sectional national telephone survey of French adults aged 18 to 64 years, which recruited a total of 2167 smokers $(2016: n=1238 ; 2017: n=929)$. Data were weighted to be representative of the French adult population. The association between study wave and cross-country tobacco purchases was examined across study waves using a multivariable logistic regression model (adjusted ORs: $\mathrm{OR}_{\mathrm{a}}(95 \% \mathrm{CI})$ ).

\section{Results}

Less than half (38.5\%) of smokers declared cross-border tobacco purchases in the last year, which were mostly done on occasional basis: $22.6 \%$ purchased tobacco cross-border once or twice yearly. In 2017, as compared with 2016, cross-border tobacco purchases by French smokers decreased $\left(\mathrm{OR}_{\mathrm{a}}=0.81[0.68-0.98]\right)$. Other factors associated with cross-border tobacco purchases included sex, and driving distance to a border.

\section{Conclusion}

In France, the increase in tobacco products price and the introduction of plain packaging did not contribute to increasing rates of out-of-country purchases of tobacco products, probably due to the overall decrease in smoking levels. However, a harmonization of tobacco products prices and 
plain packaging policies across Europe might further improve tobacco control throughout the continent. 


\section{INTRODUCTION}

Despite a steady decline related to the gradual introduction of tobacco control measures, the prevalence of smoking remains high in Europe.[1] In France, after decades when smoking rates stagnated around 30\%,[2] tobacco control policies were intensified with the National Smoking Reduction Programme (PNRT).[3,4] This programme includes a progressive increase in tobacco product prices, better coverage of nicotine replacement therapy products by the national health insurance system, a ban on smoking in parks, nationwide smoking cessation campaigns, as well as the introduction of standardised plain packaging with larger than previously health messages.[3,4] As of January $1^{\text {st }} 2017$, only plain packaging tobacco products are authorized for sale in France. [5] In parallel, there was an average increase in the price of tobacco products of $2.7 \%$ compared to 2016 (mainly roll your own (RYO) tobacco).[6] These measures have led to a sharp decrease in smoking prevalence, deemed as a great public health success.[7,8]

Increases in tobacco-related taxes and the introduction of plain packaging have been proven effective in modifying smoking-related behaviours: switch to cheaper tobacco products, reduction in tobacco consumption and higher smoking cessation levels.[9-13] However, some smokers try to circumvent these measures by using legal tax avoidance strategies, such as outof-country tobacco purchases from neighbouring countries with cheaper tobacco products and this argument is frequently brought up by opponents of stricter anti-tobacco policies.

Across the EU, it is legal to buy and travel with up to 800 cigarettes (40 packs or 4 cartridges) in-between countries,[14] and more than 10\% of smokers in France reported buying tobacco products in another EU country and 1-2\% outside of the EU (2006-2008).[15] This may not be surprising considering that France is bordered by 7 countries: Belgium, Luxembourg, Germany, Switzerland, Italy, Spain and Andorra. In 2017, none of these countries had introduced plain tobacco packaging. Moreover, with the exception of Switzerland, the average price of a pack of manufactured cigarettes for the most frequently sold brands in 2016 
was higher in France (7.00 euros),[16] than in all of those countries aside from Switzerland: ranging from 3.50 euros in Andorra,[17] to 6.32 euros in Belgium.[18-22] Applying current rules on the legal import of tobacco products (each person is limited to a maximum of 300 units from Andorra or 800 units from the other bordering countries), $[14,23]$ the amount of money a person could save when buying a carton of cigarettes ranges from 27.20 euros in the purchase was made in Belgium to 86 euros if it was in Spain. For roll your own (RYO) tobacco products, equivalent figures for a box (limited to $400 \mathrm{~g}$ per person from Andorra and $1000 \mathrm{~g}$ from the other bordering countries) are 59 euros when buying in Andorra to 150.50 euros in Luxembourg. Naturally, these estimates do not take into account the cost of travel across the border, which varies with the distance travelled for persons travelling by car or train.

Previous studies showed that smokers living near a border are more likely to buy tobacco products across the border if they are cheaper.[24,25] However, it is not yet known whether the introduction of plain tobacco packaging and the gradual increases in the price of tobacco such as implemented in France, lead smokers to buy more frequently from abroad, whether it is by crossing the border with the purpose of buying tobacco, or on another work-related or personal occasion. Further, tobacco-related behaviours are reportedly marked by sex-differences,[26,27] which have resulted in a call for systematic gender analysis in studies on tobacco control policies and smoking behaviour.[28]

The present study examines changes in cross-border purchases of tobacco products in relation to the intensification of tobacco control. 


\section{METHODS}

\section{DePICT: Study design, settings and participants}

Data come from the DePICT (Description des Perceptions, Images, et Comportements liés au Tabagisme) repeated cross-sectional survey, which took place in two waves one year apart: between the end of August and mid-November 2016 (wave 1, $\mathrm{n}=4456$ ) and beginning of September and end of November 2017 (wave 2, $n=4114$ ). Trained interviewers from a polling company (MV2) recruited participants from randomly generated telephone lists using a computer-assisted telephone interviewing (CATI) system. Landline and mobile phone numbers were called up to 30 times and one French-speaking adult, aged between 18 and 64, was randomly selected from each household using the Kish method. The study sample was based on a simple random sampling of households and individuals within households. A second polling company (CDA) was responsible for monitoring and auditing data collection procedures. DePICT was approved by the ethical review committee of the French National Institute of Health and Medical Research (INSERM, CEEI-IRB 00003888). Only regular (at least one cigarette/day) and occasional smokers (less than one cigarette/day) participating in the two study waves $(n=2167)$ were included (non-smokers and former smokers, $n=6303$, were excluded).

\section{Main outcome: cross-border tobacco purchases}

Participants were asked about their smoking status - those who responded that they were regular or occasional smokers were asked how many times they bought cigarettes or roll your own (RYO) tobacco products abroad in the preceding 12 months (never, once or twice, 3 to 9 times, 10 to 20 times, more than 20 times). Answers were dichotomized to create the outcome variable (at least one out-of-country tobacco purchase in the preceding 12 months (yes vs. no)). 


\section{Other covariates}

Covariates included factors linked with smoking behaviour such as socio-demographic characteristics, as well the driving distance from a border:

- Socio-economic characteristics: age categorized in 4 groups (18-24, 25-34, 35-49 and $\geq 50$ years), sex (male or female), educational level $(<$ high school diploma, $\leq$ two year higher education degree and $\geq$ three year higher education degree), living circumstances (living alone, with a non-smoker, or with a smoker), and country of birth (France or other country).

- Participants' smoking habits: the number of cigarettes smoked per day, and cannabis use in the preceding year [8] (yes or no).

- Distance from a border: each participant reported the postal code of their regular residence. We calculated the shortest driving distance to the nearest border using Google Maps, with the hypothesis that smokers living near a border were more likely to buy tobacco from abroad as it is easier for them to cross the border to a neighbouring country. Driving distances were preferred to straight line distances because they reflect more accurately the paths smokers take if they want to buy cheaper tobacco across the border (Belgium, Luxembourg, Germany, Italy, Spain and Andorra). We excluded Switzerland because tobacco is not cheaper there than in France and if several driving distances were possible, we used the nearest. For each smoker, several driving distances were calculated between the coordinates of the postal code of their residence (National Institute of Statistic and Economic Studies (INSEE) database)[29] and the different routes crossing the borders to the neighbouring country. Participants were classified into 5 categories according to the smallest driving distance from a border: $<100,100$ to 199 , 200 to $299, \geq 300 \mathrm{~km}$ from a border, or living in the Greater Paris region (defined by the postal codes), which corresponds to Paris and its suburbs. Even though smokers living in the Greater Paris region are more than $300 \mathrm{~km}$ from a border, they were studied separately because compared to the general population, they tend to have higher educational level and are more 
likely to be working and to be born abroad, and are therefore more likely to travel for workrelated or personal reasons.[30] The driving distances were cross-checked to ensure each smoker were correctly classified in their respective driving distance range.

\section{Statistical analyses}

For both study waves, data were weighted based on the probability of being selected through the Kish method (ratio of the number of eligible individuals to the number of telephone lines in the household), and to match the structure of the French population in 2016 with respect to sex, age, education, region of residence and smoking experimentation, using data from the National Institute of Statistics and Economic Studies (INSEE) and the National Health Survey. [2] Multivariable logistic regression models were implemented in SAS version 9.4 to examine the relationship between study wave (2017 vs. 2016) and participants' likelihood of cross-border tobacco purchases, while adjusting for socio-demographic characteristics and other potential confounders. All the analyses were weighted using the "weight" option in SAS. We used the "normalize" statement in the "weight" option in our final models to rescale the inflation weights so that they sum up to the actual sample size. Sensitivity analysis were also carried out without the weights.

\section{Testing for interactions}

In a separate model, we tested for statistical interactions between study wave and distance to the nearest border. In another analysis we also tested an interaction between study wave and sex. Stratified analyses were carried out when the interaction term was statistically significant. 


\section{RESULTS}

Table 1 presents descriptive statistics of smokers included in the analysis according to study wave. $38.5 \%$ of smokers reported at least one cross-border tobacco purchase in the last 12 months (41\% in 2016 vs $35.2 \%$ in 2017 ), with only $15.9 \%$ of smokers reporting purchasing tobacco across the border more than twice in the last year.

\section{Intensification of tobacco control policies and cross-border tobacco purchases}

In bivariate analyses, in 2017 smokers were less likely to purchase tobacco from abroad than in $2016(\mathrm{OR}=0.85[0.71-1.01])$. This association was statistically significant $\left(\mathrm{OR}_{\mathrm{a}}=0.81[0.68\right.$ - 0.98]) after adjusting for covariates in multivariate analysis (Table 2).

\section{Other factors associated with cross-border tobacco purchases}

Other factors linked with cross-border tobacco purchase in adjusted analysis included age (1824 years vs. 50 years or more $\mathrm{OR}_{\mathrm{a}}=2.45[1.82-3.29], 25-34$ years vs. 50 years or more $\mathrm{OR}_{\mathrm{a}}=$ $2.02[1.53-2.66]), 35-49$ years vs. 50 years or more $\left.\mathrm{OR}_{\mathrm{a}}=1.39[1.08-1.79]\right)$; educational level ( $<$ high school diploma vs. $\geq$ three year higher education degree $\mathrm{OR}_{\mathrm{a}}=0.68[0.51-0.92]$, $\leq$ two year higher education degree vs. $\geq$ three year higher education degree $\mathrm{OR}_{\mathrm{a}}=0.71[0.53$ - 0.96]), and country of birth (foreign country vs. France $\mathrm{OR}_{a}=2.02[1.49-2.74]$ ). Further, independently of survey wave (pooled effect), driving distance to a border was also associated with our main outcome. Those living closer to a border as well as those living in the Greater Paris region had a significantly higher odds of purchasing cigarettes abroad at least once compared to those living more than $300 \mathrm{~km}$ from a border. The likelihood of cross-border tobacco purchases increased as the distance from a border decreased $\left(\mathrm{OR}_{\mathrm{aGreaterParis}}=1.32[95 \%\right.$ CI $1.02-1.71], \mathrm{OR}_{\mathrm{a} 200-299 \mathrm{Km}}=1.47[1.05-2.04], \mathrm{OR}_{\mathrm{a} 100-199 \mathrm{Km}}=2.04[1.53-2.72], \mathrm{OR}_{\mathrm{a}}<100 \mathrm{Km}$ $=3.98[3.02-5.25])$. 


\section{Testing for interactions, and stratified analyses}

The interaction between study wave and distance from a border in relation to cross-border tobacco purchases was statistically significant $(\mathrm{p}<0.0001)$. In multivariate analyses stratified on the distance from a border, (Figure 1) the decrease in cross-border tobacco purchases between 2016 and 2017 was only observed among participants living 100-199 Km $\left(\mathrm{OR}_{\mathrm{a}}=0.57\right.$ $[0.33-0.97])$ and $200-299 \mathrm{Km}\left(\mathrm{OR}_{\mathrm{a}}=0.50[0.25-0.99]\right)$ from a border.

The interaction between study wave and sex in multivariate analysis was also statistically significant. In sex-stratified multivariate analyses, the decrease in cross-border tobacco purchases was only observed in men $\left(\mathrm{OR}_{\mathrm{a}}=0.59[0.45-0.78]\right)$ (Figure 1).

Sensitivity analyses without the weights were also statistically significant and showed the same result trends as the weighted analyses (results not shown).

\section{DISCUSSION}

\section{Key findings}

The intensification of tobacco control measures in France between 2016 and 2017, which resulted in a decrease in smoking rates, was not linked to an increase, but instead linked to a decrease in cross-border tobacco purchases. This trend appeared strongest in participants who were not living near a border, and who were male. Participants living nearest to a border with a country where tobacco prices are lower were most likely to report cross-border tobacco purchases and least likely to change behaviour after the intensification of tobacco control policies. Though, it cannot be claimed that these measures are solely responsible for this decrease, our findings suggest that strengthening anti-tobacco measures in France did not lead 
smokers to increase their purchases of cigarettes abroad, which is reassuring. Nevertheless, more harmonized anti-tobacco policies in the EU, particularly in terms of price, could help curtail smoking rates across different countries.

\section{Interpretation}

Our finding indicating a decrease in cross-border tobacco purchases after the implementation of comprehensive tobacco measures such as increase in tobacco prices and introduction of plain packaging is rather surprising. The tobacco industry often argues that these types of measures encourage tax evasion and avoidance among smokers, including tobacco purchases crossborder, in duty-free shops or on the Internet.[31,32] Nevertheless, these claims have previously been rebuked.[33] For example in Australia, the introduction of plain packaging did not increase illicit tobacco sales.[34] In France, the implementation of anti-tobacco measures has been accompanied by a decreasing in the social acceptance of smoking, an increase in the fear of the health consequences of smoking [8] and a decrease in smoking levels, [7] which could explain the decrease in out-of-country purchases we observed. Our study contributes to this existing literature by showing that the enforcement of existing anti-smoking measures did not lead to an increase in out-of-country purchases of tobacco products among smokers in France even though France is bordered by countries where tobacco products are cheaper. However, as previous studies showed, the proximity of a neighbouring country with cheaper tobacco products is linked with higher risk of out of country purchases.[35]

One interesting result is that even if male smokers were more likely to purchase tobacco cross-border overall compared to women, they were also more sensitive to new policies and decreased out-of-country purchases of tobacco products, but not women. This is consistent with previous studies showing that female smokers are less responsive to antismoking measures such as price increases.[36] 


\section{Limitations}

Our study has several limitations which need to be mentioned. First, our study was framed as a survey on smoking-related perceptions and behaviours, which may have increased the likelihood of selection bias among smokers. However, to limit this possibility, we statistically weighted all analyses to render the data and results representative of adults living in France, including in terms of smoking patterns. Second, it is possible that some of the responses are affected by recall bias; nonetheless, this bias should be comparable between the two study waves. Further, we only investigated cross-country tobacco purchases that are legal, which should limit desirability bias. However, the smuggling of tobacco products is estimated to be modest (smuggled and counterfeit cigarette consumption now accounts for $8.7 \%$ of total EU consumption in 2017 [37]) compared to legal cross-border purchasing, which amounts to up to $14-20 \%$ of legal tobacco sales in 2008,[38] while in 2017 it was estimated to be $11.5 \%$ in 2017 (12.3\% in 2016).[37,39] In our study, it is not known whether tobacco product purchases were made by smokers crossing the border on purpose, or whether smokers were on holidays or business in a foreign country when they made the purchase, which should be investigated in future studies. Furthermore, while it is reassuring that these measures did not lead to an increase in cross-border tobacco purchases, it is not possible to attribute the decrease in purchases solely to these measures as there may be other factors that we have not measured that can play a role. While there was an inflation of $1 \%$ between 2016 and 2017, with a $10.3 \%$ increase in the prices of gasoline,[6] an increase in travel was nevertheless observed, with $74.8 \%$ of the total population travelling in 2017 (74.0\% in 2016) and an average of 5.6 travels per person (4.9 in 2016),[40] yielding 25,167 travels for personal reasons and 3,888 for professional purposes were conducted in 2017 , as compared to respectively 23,544 and 2,938 in 2016.[40] So, the decrease in purchases from a foreign country cannot be attributed to a decrease in travels of the French population. 


\section{Implications}

According to the tobacco industry, tobacco control measures such as increases in taxes and plain packaging lead to higher rates of tobacco smuggling and cross-country purchases.[41] However, data from France continues to show a decrease in smoking rates as a consequence of comprehensive tobacco measures, including a drop in out-of-country tobacco purchases. These results as well as previous studies suggest that most smokers buy cigarettes out of the country only once or twice during the year, probably during their holidays.[35] These comprehensive measures are having a positive impact in terms of tobacco control, though smokers living near a border are more still likely to buy tobacco from another country compared to those living far from a border.[35] A harmonization of prices of tobacco products and plain packaging policies across Europe might further improve tobacco control throughout the continent. 


\section{What this paper adds}

What is already known on this subject?

- Tobacco control policies, including increases in taxes and plain packaging, were recently intensified in France, and resulted in a decrease in smoking rates.

- France is bordered by several countries where tobacco products are significantly cheaper.

\section{Important gaps in knowledge:}

- It has been argued that increases in taxes and plain packaging implementation would result in increases in cross-border tobacco purchases.

\section{What this study adds:}

- After the intensification of tobacco control policies in France, we report a decrease in the rates of cross-border tobacco purchases in 2017 compared to 2016

- Our results suggest that decrease in overall smoking rates, also translates into lower cross-border tobacco purchases

\section{Declarations of interests}

The authors declare no conflict of interest.

\section{Funding}

This work was supported by a grant from the French National Cancer Institute (INCA). Subvention $\mathrm{N}^{\circ} 2016-097$. The funders of the study had no role in study design, data collection, data analysis, data interpretation, writing of the report, or in the decision to submit the article for publication.

\section{Acknowledgements}

We thank members of the DePICT scientific committee: François Beck (OFDT), Renaud Crespin (CNRS), Karine Gallopel-Morvan (EHESP), Gwenn Menvielle (INSERM), Brigitte 
Metadieu (Association Charonne), Viet Nguyen-Than (ANSP), and Patrick Peretti-Watel (INSERM) for their help in discussing the study protocol, questionnaire, and planned analyses. We also want to acknowledge Carla Estaquio and Antoine Deutsch from the French National Cancer Institute (INCa).

We also like to acknowledge "MV2" polling institute, as well as "CDA" for monitoring and auditing the study's execution. 


\section{References}

1 Bilano V, Gilmour S, Moffiet T, et al. Global trends and projections for tobacco use, 1990-2025: an analysis of smoking indicators from the WHO Comprehensive Information Systems for Tobacco Control. The Lancet 2015;385:966-76. doi:10.1016/S0140-6736(15)60264-1

2 Pasquereau A, Gautier A, Andler R, et al. Tabac et e-cigarette en France : niveaux d'usage d'après les premiers résultats. BEH. 2017.http://www.camip.info/nous-avons-lupour-vous/sante-au-travail-et-sante-publique/Addictions/article/tabac-et-e-cigarette-enfrance (accessed 7 Nov 2017).

3 Plan cancer 2014-2019. Ministère des affaires sociales, de la santé et des droits des femmes 2015. https://www.ecancer.fr/content/download/123552/1485522/file/Plan_cancer_2014-2019-PNRT.pdf

4 McNeill A, Guignard R, Beck F, et al. Understanding increases in smoking prevalence: case study from France in comparison with England 2000-10. Addiction 2015;110:392400. doi:10.1111/add.12789

5 Décret $\mathrm{n}^{\circ}$ 2016-334 du 21 mars 2016 relatif au paquet neutre des cigarettes et de certains produits du tabac. 2016.

6 Institut National de la Statistique et des Etudes Economiques. Consumer prices accelerated on average from 2016 to 2017 - Price Index - Annual average rates of change - year 2017, France. 2018.https://www.insee.fr/en/statistiques/3307940\#consulter (accessed 27 Jan 2020).

7 Andler R, Richard J-B, Guignard R, et al. Baisse de la prévalence du tabagisme quotidien parmi les adultes : Résultats du baromètre de santé publique France 2018. 2019.

8 El-Khoury F, Bolze C, Gomajee R, et al. Lower smoking rates and increased perceived harm of cigarettes among French adults one year after comprehensive tobacco control measures. Drug and Alcohol Dependence 2019;201:65-70. doi:10.1016/j.drugalcdep.2019.03.025

9 Hanewinkel R, Isensee B. Five in a row-reactions of smokers to tobacco tax increases: population-based cross-sectional studies in Germany 2001-2006. Tobacco Control 2007;16:34-7. doi:10.1136/tc.2006.017236

$10 \mathrm{Xu}$ X, Pesko MF, Tynan MA, et al. Cigarette Price-Minimization Strategies by U.S. Smokers. American Journal of Preventive Medicine 2013;44:472-6. doi:10.1016/j.amepre.2013.01.019

11 Dunlop SM, Perez D, Cotter T. Australian smokers' and recent quitters' responses to the increasing price of cigarettes in the context of a tobacco tax increase: Responses to a cigarette price increase. Addiction 2011;106:1687-95. doi:10.1111/j.13600443.2011.03492.x 
12 Choi K, Boyle RG. Changes in cigarette expenditure minimising strategies before and after a cigarette tax increase. Tob Control 2018;27:99-104. doi:10.1136/tobaccocontrol2016-053415

13 Betzner A, Boyle RG, St Claire AW. Price-Minimizing Behaviors in a Cohort of Smokers before and after a Cigarette Tax Increase. Int J Environ Res Public Health 2016;13. doi:10.3390/ijerph13060608

14 Rapporter du tabac de l'étranger. https://www.servicepublic.fr/particuliers/vosdroits/F804 (accessed 6 Aug 2019).

15 Guindon GE, Driezen P, Chaloupka FJ, et al. Cigarette tax avoidance and evasion: findings from the International Tobacco Control Policy Evaluation (ITC) Project. Tobacco Control 2014;23:113-22. doi:10.1136/tobaccocontrol-2013-051074

16 World Health Organization. WHO report on the global tobacco epidemic, 2017. Country profile: France. 2017.

https://www.who.int/tobacco/surveillance/policy/country_profile/fra.pdf?ua=1 (accessed 6 Aug 2019).

17 World Health Organization. WHO report on the global tobacco epidemic, 2017. Country profile: Belgium. 2017.

https://www.who.int/tobacco/surveillance/policy/country_profile/bel.pdf?ua=1 (accessed 6 Aug 2019).

18 World Health Organization. WHO report on the global tobacco epidemic, 2017. Country profile: Spain. 2017.

https://www.who.int/tobacco/surveillance/policy/country_profile/esp.pdf?ua=1 (accessed 6 Aug 2019).

19 World Health Organization. WHO report on the global tobacco epidemic, 2017. Country profile: Luxembourg. 2017.

https://www.who.int/tobacco/surveillance/policy/country_profile/lux.pdf?ua=1 (accessed 6 Aug 2019).

20 World Health Organization. WHO report on the global tobacco epidemic, 2017. Country profile: Germany. 2017.

https://www.who.int/tobacco/surveillance/policy/country_profile/deu.pdf?ua=1 (accessed 6 Aug 2019).

21 World Health Organization. WHO report on the global tobacco epidemic, 2017. Country profile: Italy. 2017.

https://www.who.int/tobacco/surveillance/policy/country_profile/ita.pdf?ua=1 (accessed 6 Aug 2019).

22 World Health Organization. WHO report on the global tobacco epidemic, 2017. Country profile: Andorra. 2017.

https://www.who.int/tobacco/surveillance/policy/country_profile/and.pdf?ua=1

23 Passer la douane à Andorre : taxes et franchise | Portail de la Direction Générale des Douanes et Droits Indirects. https://www.douane.gouv.fr/passer-la-douane-andorre-taxeset-franchise (accessed 24 Oct 2019). 
24 Stoklosa M. Prices and cross-border cigarette purchases in the EU: evidence from demand modelling. Tobacco Control 2018;:tobaccocontrol-2018-054678.

doi:10.1136/tobaccocontrol-2018-054678

25 Agaku IT, Blecher E, Filippidis FT, et al. Impact of cigarette price differences across the entire European Union on cross-border purchase of tobacco products among adult cigarette smokers. Tobacco Control 2016;25:333-40. doi:10.1136/tobaccocontrol-2014052015

$26 \mathrm{Ng} \mathrm{M}$, Freeman MK, Fleming TD, et al. Smoking prevalence and cigarette consumption in 187 countries, 1980-2012. JAMA 2014;311:183-92. doi:10.1001/jama.2013.284692

27 Smith PH, Bessette AJ, Weinberger AH, et al. Sex/gender differences in smoking cessation: A review. Prev Med 2016;92:135-40. doi:10.1016/j.ypmed.2016.07.013

28 Amos A, Greaves L, Nichter M, et al. Women and tobacco: a call for including gender in tobacco control research, policy and practice. Tobacco Control 2012;21:236-43. doi:10.1136/tobaccocontrol-2011-050280

29 Base officielle des codes postaux - data.gouv.fr. /fr/datasets/base-officielle-des-codespostaux/ (accessed 28 Jan 2020).

30 L'état de santé de la population en France - Rapport 2017. Direction de la recherche, des études, de l'évaluation et des statistiques / Santé publique France https://drees.solidaritessante.gouv.fr/IMG/pdf/esp2017.pdf (accessed 2 Aug 2019).

31 Smith KE, Savell E, Gilmore AB. What is known about tobacco industry efforts to influence tobacco tax? A systematic review of empirical studies. Tobacco Control 2013;22:e1-e1. doi:10.1136/tobaccocontrol-2011-050098

32 Stoklosa M, Ross H. Contrasting academic and tobacco industry estimates of illicit cigarette trade: evidence from Warsaw, Poland. Tobacco Control 2014;23:e30-4. doi:10.1136/tobaccocontrol-2013-051099

33 Rowell A, Evans-Reeves K, Gilmore AB. Tobacco industry manipulation of data on and press coverage of the illicit tobacco trade in the UK. Tobacco Control 2014;23:e35-43. doi:10.1136/tobaccocontrol-2013-051397

34 Scollo M, Zacher M, Coomber K, et al. Use of illicit tobacco following introduction of standardised packaging of tobacco products in Australia: results from a national crosssectional survey. Tobacco Control 2015;24:ii76-81. doi:10.1136/tobaccocontrol-2014052072

35 Lermenier-Jeannet A, Palle C. Enquête ATLAS 2016 : principaux résultats Approvisionnement en tabac : lieux d'achat sollicités par les fumeurs français. OFDT 2017. https://www.ofdt.fr/BDD/publications/docs/eisxaly7.pdf

36 Ngo A, Fong GT, Craig LV, et al. Analysis of Gender Differences in the Impact of Taxation and Taxation Structure on Cigarette Consumption in 17 ITC Countries. Int J Environ Res Public Health 2019;16. doi:10.3390/ijerph16071275 
37 KPMG. A study of the illicit cigarette market in the European Union, Norway and Switzerland. 2018.

https://assets.kpmg/content/dam/kpmg/uk/pdf/2018/07/project_sun_executive_summary_ 2018.pdf (accessed 30 Jan 2020).

38 Lakhdar CB. Quantitative and qualitative estimates of cross-border tobacco shopping and tobacco smuggling in France. Tob Control 2008;17:12-6. doi:10.1136/tc.2007.020891

39 Rapport KPMG 2017 : 24,6 \% de marché parallèle | Le Monde du Tabac. http://www.lemondedutabac.com/rapport-kpmg-2017-246-de-marche-parallele/ (accessed 30 Jan 2020).

40 Direction Générale des Entreprises. Les déplacements touristiques des français. 2018. https://www.entreprises.gouv.fr/files/files/directions_services/etudes-et-statistiques/statstourisme/memento/2018/MEMENTO_TOURISME_Edt2018-Chapitre5.pdf (accessed 28 Jan 2020).

41 Joossens L, Raw M. Cigarette smuggling in Europe: who really benefits? Tobacco Control 1998;7:66-71. doi:10.1136/tc.7.1.66 
Tables

Table 1. Characteristics of study participants depending on the waves of survey: Chi square test and ANOVA. Nationally representative DePICT study, France, 2016 \& 2017, $\mathrm{N}=\mathbf{2 1 6 7}$

\begin{tabular}{|c|c|c|c|}
\hline Variables & $\begin{array}{l}\text { Wave 1, } 2016 \\
\qquad(\mathrm{n}=1238)\end{array}$ & $\begin{array}{l}\text { Wave 2, } 2017 \\
\qquad(\mathrm{n}=929)\end{array}$ & $p$ \\
\hline Age & $39.7(\mathrm{SD}=12.8)$ & $43.1(\mathrm{SD}=12.8)$ & $<0.0001$ \\
\hline Sex: Female & $612(49.4 \%)$ & $432(46.5 \%)$ & 0.1763 \\
\hline $\begin{array}{l}\text { Educational level } \\
<\text { high school diploma } \\
\leq 2 \text { year higher education degree } \\
\geq 3 \text { year higher education degree }\end{array}$ & $\begin{array}{l}458(37.0 \%) \\
499(40.3 \%) \\
281(22.7 \%)\end{array}$ & $\begin{array}{l}341(42.7 \%) \\
354(36.7 \%) \\
234(45.4 \%)\end{array}$ & 0.3587 \\
\hline $\begin{array}{l}\text { Living situation } \\
\text { Live alone } \\
\text { Live with non-smoker } \\
\text { Live with smoker }\end{array}$ & $\begin{array}{l}464(37.5 \%) \\
366(29.6 \%) \\
408(33.0 \%)\end{array}$ & $\begin{array}{l}345(37.1 \%) \\
296(31.9 \%) \\
288(31.0 \%)\end{array}$ & 0.4570 \\
\hline Born in a foreign country & $113(9.1 \%)$ & $86(9.3 \%)$ & 0.9176 \\
\hline Number of cigarettes/day & $12.0(\mathrm{SD}=9.9)$ & $11.5(\mathrm{SD}=9.0)$ & 0.2047 \\
\hline $\begin{array}{l}\text { Smoked cannabis in the last } \\
\text { year }\end{array}$ & $344(27.8 \%)$ & $215(23.1 \%)$ & 0.0145 \\
\hline Driving Distance from border & & & 0.0253 \\
\hline$<100 \mathrm{~km}$ & $167(13.5 \%)$ & $136(14.6 \%)$ & \\
\hline $100-199 \mathrm{~km}$ & $150(12.1 \%)$ & $119(12.8 \%)$ & \\
\hline $200-299 \mathrm{~km}$ & $116(9.4 \%)$ & $72(7.8 \%)$ & \\
\hline$>300 \mathrm{~km}$ & $559(45.2 \%)$ & $461(49.6 \%)$ & \\
\hline Greater Paris & $246(19.9 \%)$ & $141(15.2 \%)$ & \\
\hline $\begin{array}{l}\text { Bought tobacco abroad } \\
\text { Never } \\
\text { Once or twice } \\
3 \text { to } 9 \text { times } \\
10 \text { to } 20 \text { times }\end{array}$ & $\begin{array}{l}730(59.0 \%) \\
302(24.4 \%) \\
116(9.4 \%) \\
39(3.2 \%)\end{array}$ & $\begin{array}{c}602(64.8 \%) \\
188(20.2 \%) \\
80(8.6 \%) \\
34(3.7 \%)\end{array}$ & 0.0488 \\
\hline
\end{tabular}


More than 20 times

Table 2. Changes in cross-border tobacco purchases after the intensification of tobacco control policies (adjusted Odds Ratios and 95\% Confidence Intervals). Nationally representative DePICT study, France, $2016 \& 2017, \mathrm{n}=2167$.

\begin{tabular}{|c|c|c|c|c|}
\hline & $\begin{array}{l}\text { Odds } \\
\text { Ratios }\end{array}$ & \multicolumn{2}{|c|}{$\begin{array}{l}\text { 95\% Confidence } \\
\text { Interval }\end{array}$} & $p$ \\
\hline Wave: 2017 vs 2016 & 0.85 & 0.71 & 1.01 & 0.0585 \\
\hline \multicolumn{5}{|l|}{ Multivariable adjusted analysis } \\
\hline Wave: 2017 vs 2016 & 0.81 & 0.68 & 0.98 & 0.0274 \\
\hline \multicolumn{5}{|l|}{ Distance to nearest border } \\
\hline$<100 \mathrm{~km} v \mathrm{~s}>300 \mathrm{~km}$ & 3.98 & 3.02 & 5.25 & $<.0001$ \\
\hline $100-199 \mathrm{~km}$ vs $>300 \mathrm{~km}$ & 2.04 & 1.53 & 2.72 & \\
\hline $200-299 \mathrm{~km} v s>300 \mathrm{~km}$ & 1.47 & 1.05 & 2.04 & \\
\hline Greater Paris vs $>300 \mathrm{~km}$ & 1.32 & 1.02 & 1.71 & \\
\hline Sex: Female vs Male & 0.92 & 0.77 & 1.11 & 0.4028 \\
\hline Educational Level & & & & 0.0353 \\
\hline $\begin{array}{l}<\text { high school diploma vs } \geq 3 \text { year higher } \\
\text { education degree }\end{array}$ & 0.68 & 0.51 & 0.92 & \\
\hline
\end{tabular}




\begin{tabular}{|l|c|c|c|c|}
\hline $\begin{array}{l}\leq 2 \text { year higher education degree vs } \geq 3 \\
\text { year higher education degree }\end{array}$ & $\mathbf{0 . 7 1}$ & 0.53 & 0.96 & \\
\hline Age & & & & \\
\hline $18-24$ vs $\geq 50$ & $\mathbf{2 . 4 5}$ & 1.82 & 3.29 & \\
\hline $25-34$ vs $\geq 50$ & $\mathbf{2 . 0 2}$ & 1.53 & 2.66 & \\
\hline $35-49$ vs $\geq 50$ & $\mathbf{1 . 3 9}$ & 1.08 & 1.79 & \\
\hline Number of cigarettes/day: & & & & \\
\hline $10-19$ vs $<10$ & $\mathbf{1 . 7 3}$ & 1.38 & 2.17 & \\
\hline 20 vs $<10$ & $\mathbf{1 . 5 5}$ & 1.21 & 1.97 & \\
\hline Born in a foreign country: yes vs no & $\mathbf{2 . 0 2}$ & 1.49 & 2.74 & $<.0001$ \\
\hline Living conditions & & & & \\
\hline Alone vs with non-smoker & $\mathbf{1 . 2 3}$ & 0.99 & 1.53 & 0.0600 \\
\hline With smoker vs with non-smoker & & & & \\
\hline Cannabis in the last year: yes vs no & & & & \\
\hline
\end{tabular}


Figure 1. Changes in out-of-country tobacco purchases after the intensification of tobacco control policies: adjusted analyses stratified on the driving distance to the nearest border, and sex (adjusted Odds Ratios and 95\% Confidence Intervals). Nationally representative DePICT study, France, $2016 \& 2017, \mathrm{n}=2167$.

The odds ratios compare the odds of cross-border purchasing in 2017 vs 2016 for each distance band and for both sexes.

*Adjusted on: sex, age, educational level, wave, number of cigarettes smoked per day, country of birth, cannabis use in the last 12 months, living conditions (living alone, with a non-smoker, or with a smoker).

**Adjusted on: age, educational level, wave, number of cigarettes smoked per day, country of birth, cannabis use in the last 12 months, living conditions (living alone, with a non-smoker, or with a smoker), and driving distance.

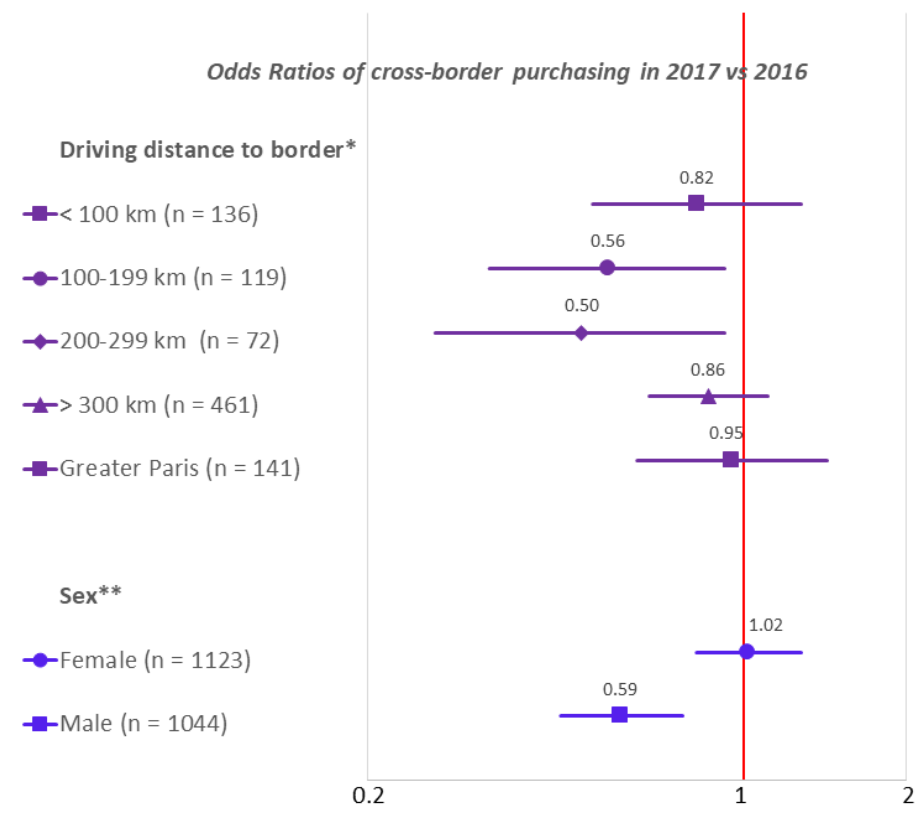

